\title{
PENERAPAN INTERNET OF THINGS PADA SISTEM PENGENDALIAN BARANG ELEKTRONIK RUMAH DAN SUHU RUANGAN
}

\author{
Evans Fuad ${ }^{1}$, Mitra Unik², Hendra Adi Suseno ${ }^{3}$ \\ ${ }^{123}$ Fakultas Ilmu Komputer, Universitas Muhammadiyah Riau \\ 1e-mail: evansfuad@umri.ac.id \\ 2email: mitraunik@umri.ac.id \\ 3email: hendraadi@student.umri.ac.id
}

\begin{abstract}
Internet of things is a set of interconnected devices and communicate with each other through the internet network. With the human habit of leaving home with the state of electrical equipment still alive, this triggers the addition of energy that goes on and raises the payment of electricity payments that must be issued. for example the small thing that is like a lamp. In addition to waste of electricity there are also some risks that result in short-circuit, this happens because when electricity flows in a conductor, there is some energy converted into heat. The larger the electricity that flows, the more heat generated. It requires a system of controlling electronic goods programmed through a computer that controls some equipment and electrical equipment or electronic devices. Starting from the lighting arrangement, and various household appliances that can be controlled via remote control. Therefore in this study built an Internet-based system of Things that can be used on a web-based system. As an electronic device controller the author uses Arduino Uno as the core microcontroller of the tool.
\end{abstract}

Keywords: Web, Microcontroller, Internet of Things.

Internet of things adalah sekumpulan perangkat yang saling berhubungan dan saling berkomunikasi melalui jaringan internet. Dengan kebiasaan manusia yang meninggalkan rumah dengan keadaan peralatan listrik masih hidup, ini memicu penambahan energi yang terus berjalan dan menimbulkan pembekakan pembayaran listrik yang harus dikeluarkan. Contoh hal yang kecilnya yaitu seperti lampu. Selain pemborosan listrik juga terdapat beberapa resiko yang mengakibatkan arus pendek, ini terjadi karna ketika listrik mengalir dalam suatu konduktor, ada sebagian energinya yang terkonverensi menjadi panas. Semakin besar listrik yang mengalir, semakin banyak panas yang dihasilkan. Untuk itu dibutuhkan sistem pengendalian barang elektronik yang terprogram melalui sebuah komputer yang mengendalikan beberapa perlengkapan dan peralatan listrik atau perangkat elektronik. Mulai dari pengaturan tata lampu, dan berbagai alat-alat rumah tangga yang dapat dikendalikan melalui kendali jarak jauh. Maka dari itu pada penelitian ini dibangun sebuah sistem berbasis Internet of Things yang dapat digunakan pada sistem berbasis web. Sedangkan sebagai pengontrol perangkat elektroniknya penulis menggunakan Arduino Uno sebagai mikrokontroller inti dari alat.

Keywords: Web, Mikrokontroller, Internet of Things

\section{PENDAHULUAN}

Dalam perkembangan ilmu teknologi di bidang elektronika dan komunikasi sekarang ini banyak manfaat yang biasa dirasakan oleh lapisan masyarakat. Seiring dengan kebutuhan masyarakat dan teknologi yang semakin canggih, dibuatlah suatu sistem pengendalian peralatan rumah yang mampu di kendalikan dengan wibsite, yang bertujuan untuk mempermudah pekerjaan manusia. Perkembangan ilmu pengetahuan dan teknologi pada masa sekarang terus diikuti oleh sebagian bahkan hampir semua kalangan (Setiani dkk, 2015).

Termasuk perkembangan pendingin ruangan atau Air Conditioner (AC). Penggunaan 
teknologi ini termasuk tinggi, apalagi di kotakota besar. Cuaca yang ekstrem saat ini membuat suhu yang terus berubah-ubah atau sering dikatakan anomali cuaca. Penggunaan Air Conditioner (AC) sebagai alternatif untuk mengganti ventilasi alami dapat meningkatkan kenyamanan dan produktivitas manusia. Namun penggunaan $\mathrm{AC}$ ini dapat memberikan dampak negatif pada lingkungan, yaitu merusaknya lapisan ozon. Untuk mengurangi dampak negatif tersebut, salah satunya dengan cara meningkatkan efisiensi penggunaan $\mathrm{AC}$ dalam satu ruangan, yaitu menyesuaikan kebutuhan pemakaian suhu ruangan sesuai dengan kebutuhan yang akan diperlukan (Damayanti dkk, 2014).

Permasalahan yang selalu terjadi pada masyarakat salah satunya yaitu adalah pemborosan listrik ketika kebiasaan manusia meninggalkan rumah dengan keadaan peralatan listrik masih hidup, contoh hal kecilnya seperti lampu. Ini memicu terjadinya penambahan energi yang terus berjalan atau pembekakan pembayaran listrik yang harus dikeluarkan. Selain pemborosan listrik dikawatirkan juga beberapa resiko yang mengakibatkan arus pendek, ini terjadi karna ketika listrik mengalir dalam suatu konduktor, ada sebagian energi nya yang terkonverensi menjadi panas. Semangkin besar listrik yang mengalir, semangkin banyak panas yang dihasilkan. Jika arus listrik tidak dihambat maka listrik tersebut mengalir dalam arus yang tak terhingga besar nya sehingga panas yang terbentuk akan bersifat destruktif, setidaknya kabel terbakar. Oleh sebab itu dibutuhkanya sebuah sistem yang mampu mengendalikan atau memonitor pemakaian daya dalam suatu ruangan pada alat - alat rumah tangga tersebut dari jarak jauh (Andrianto dkk, 2015).

\section{KONSEP DASAR FRAMEWORK}

Menurut (Fajriyah, 2010) PHP adalah sebuah bahasa pemrograman yang memungkinkan seorang developer (programmer atau system analyst) membuat sebuah aplikasi berbasis webyang powerful sekaligus mampu mengampu database berskala besar. Dalam perkembangannya, seorang programmer PHP seringkali dituntut untuk menyelesaikan berbagai macam aplikasi dengan tingkat kerumitan yang cukup tinggi dalam waktu singkat.

\section{ARDUINO UNO}

Apakah arduino Menurut (Djuandi, 2011) Arduino merupakan sebuah board minimum system mikrokontroler yang bersifat open source. Didalam rangkaian board arduino terdapat mikrokontroler AVR seri ATMega 328 yang merupakan produk dari Atmel.

Arduino memiliki kelebihan tersendiri dibanding board mikrokontroler yang lain selain bersifat open source, arduino juga mempunyai bahasa pemrogramanya sendiri yang berupa bahasa C. Selain itu dalam board arduino sendiri sudah terdapat loader yang berupa USB sehingga memudahkan kita ketika kita memprogram mikrokontroler didalam arduino. Sedangkan pada kebanyakan board mikrokontroler yang lain yang masih membutuhkan rangkaian loader terpisah untuk memasukkan program ketika kita memprogram mikrokontroler. Port USB tersebut selain untuk loader ketika memprogram, bisa juga difungsikan sebagai port komunikasi serial.

\section{WIRELESS}

ESP8266 merupakan modul wifi yang berfungsi sebagai perangkat tambahan mikrokontroler seperti arduino agar dapat terhubung langsung dengan wifi dan membuat koneksi TCP/IP (Rizal (2014).

Modul ini membutuhkan daya sekitar 3.3v dengan memiliki tiga mode wifi yaitu Station, Access Point dan Both (Keduanya). Modul ini juga dilengkapi dengan prosesor, memori dan GPIO dimana jumlah pin bergantung dengan jenis ESP8266 yang kita gunakan. Sehingga modul ini bisa berdiri sendiri tanpa menggunakan mikrokontroler apapun karena sudah memiliki perlengkapan layaknya mikrokontroler.

\section{MIKROKONTROLLER}

Mikrokontroller adalah sebuah rangkaian terpadu tunggal, dimana semua blok rangkaian yang kita jumpai sebagai unit-unit terpisah didalam sebuah komputer digabungkan menjadi satu (Bishop, 2014). 
Terdapat ratusan jenis mikrokontroller yang berbeda, yang tersedia di pasaran. Sedemikian beragamnya, sehingga cukup sulit bagi kita untuk mengatakan jenis mana yang merupakan jenis tipikal.

\section{PERANCANGAN APLIKASI}

Perancangan aplikasi merupakan merancang sebuah tampilan antar muka yang baik dan mudah di pahami oleh pengguna yang direpresentasi dari suatu proses atau alur dalam sistem dengan tujuan mendefinisikan suatu sistem dalam bentuk model.

Berdasarkan pada gambar 1 menjelaskan alur sistem yang akan dibuat. Dimulai dengan menampilkan menu login terlebih dahulu dan masuk kemenu utama yang berupa daftar dari saklar lampu, saklar tv, saklar kipas angin, dan saklar kulkas.

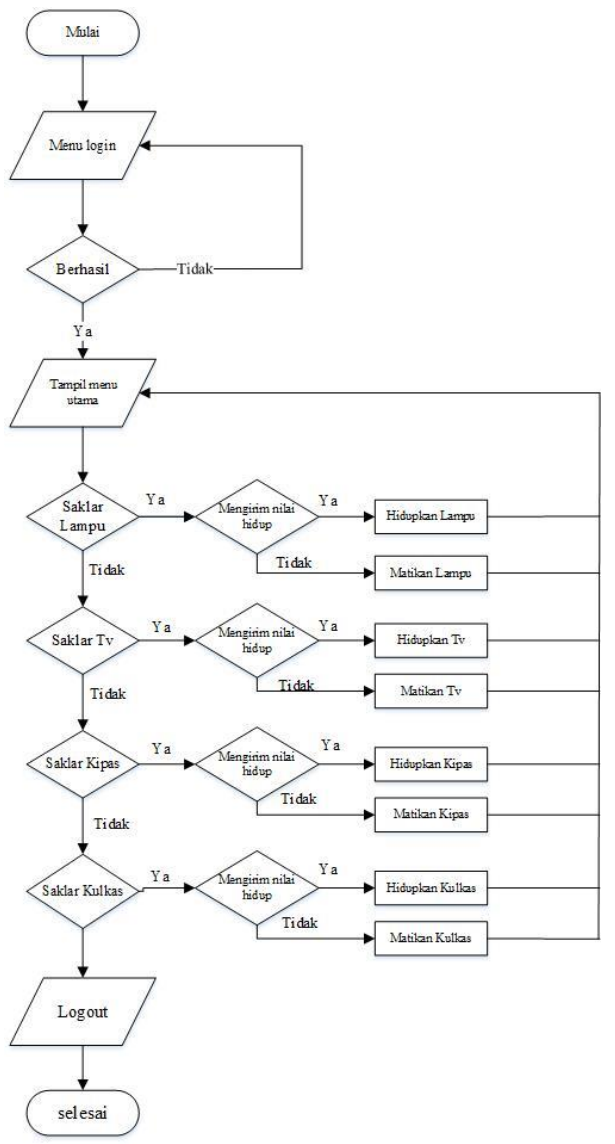

Gambar 1. Alur Sistem

PERANCANGAN ALAT
Perancangan alat merupakan representasi dari suatu proses atau alur dalam sistem dengan tujuan mendefinisikan suatu sistem dalam bentuk model.

Berdasarkan pada gambar berikut ini rangkaian alat untuk membuat pengendalian barang elektronik rumah.

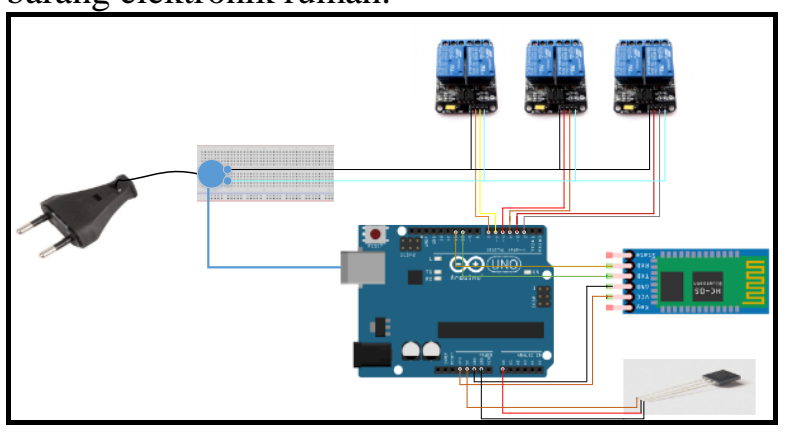

Gambar 2. Rangkaian Alat

\section{IMPLEMENTASI}

implementasi dan pengujian sistem merupakan tahap dimna sistem siap dioperasikan pada keadaan yang sebenarmya, sehingga diketahui apakah sistem yang sudah di perbaharui dapat menghasilkan tujuan yang diinginkan.

\section{TAMPILAN MENU UTAMA}

Halaman utama adalah halaman yang pertama kali saat melwati proses login dan akses untuk menjalankan sistem. Pada gambar ini terlihat tampilan menu utama pada Web yang menampilkan daftar menu kontrol dari lampu, televisi, kipas angin, dan kulkas.

\section{TAMPILAN UTAMA KEADAAN MATI}

Berikut contoh gambar icon perangkat elektronik rumah, dalam tampilan menu disistem dalam kondisi mati.

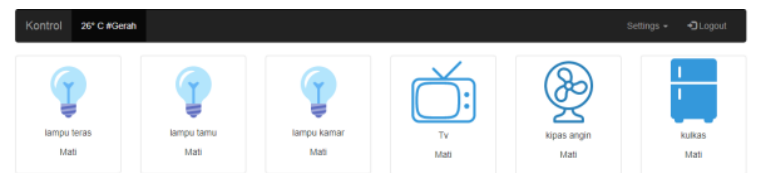

\section{Gambar 3. Tampilan Menu Utama}

Berikut contoh gambar alat dalam kondisi keadaan mati. Dimana alat tersebut yang akan 
mengontrol barang elektronik rumah yang dikontrol dari sistem bebasis.

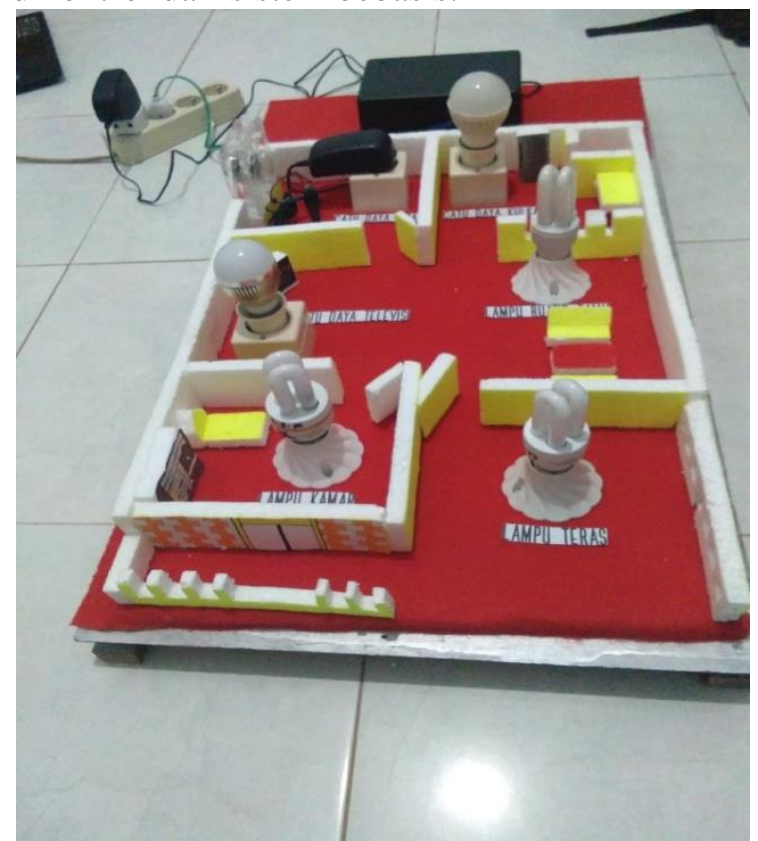

Gambar 5. Alat Dalam Kondisi Mati

\section{TAMPILAN UTAMA KEADAAN HIDUP}

Berikut contoh gambar icon perangkat elektronik rumah, dalam tampilan menu disistem dalam kondisi hidup.

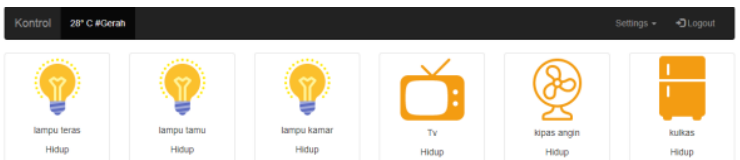

\section{Gambar 6. Utama Kondisi Hidup}

Sistem memerintahkan barang elektronik rumah seperti lampu, televisi, kulkas dan kipas angin.

Berikut hasil institusi sistem dalam menghidupkan barang elektronik rumah

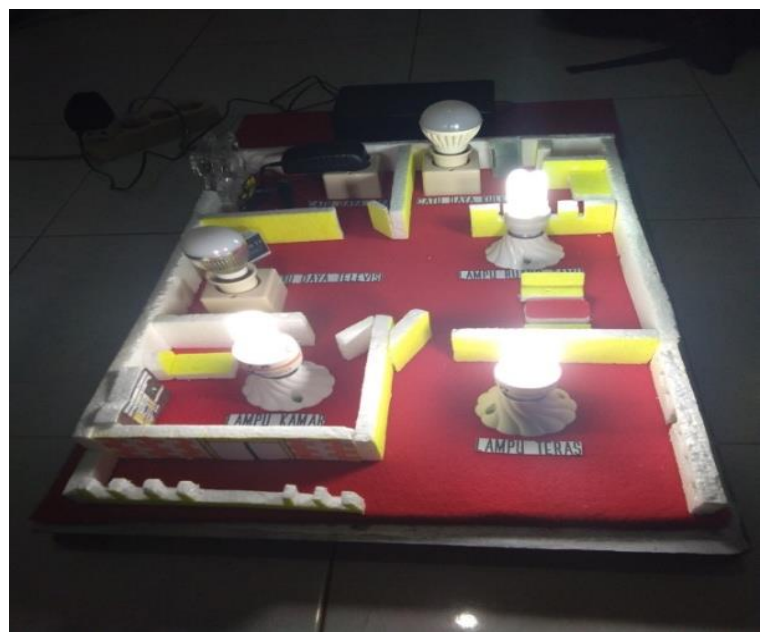

Gambar 7. Lampu Dalam Keadaan Hidup

Pada gambar diatas simulasi alat menunjukan perangkat elektronik rumah berupa lampu dalam keadaan hidup.

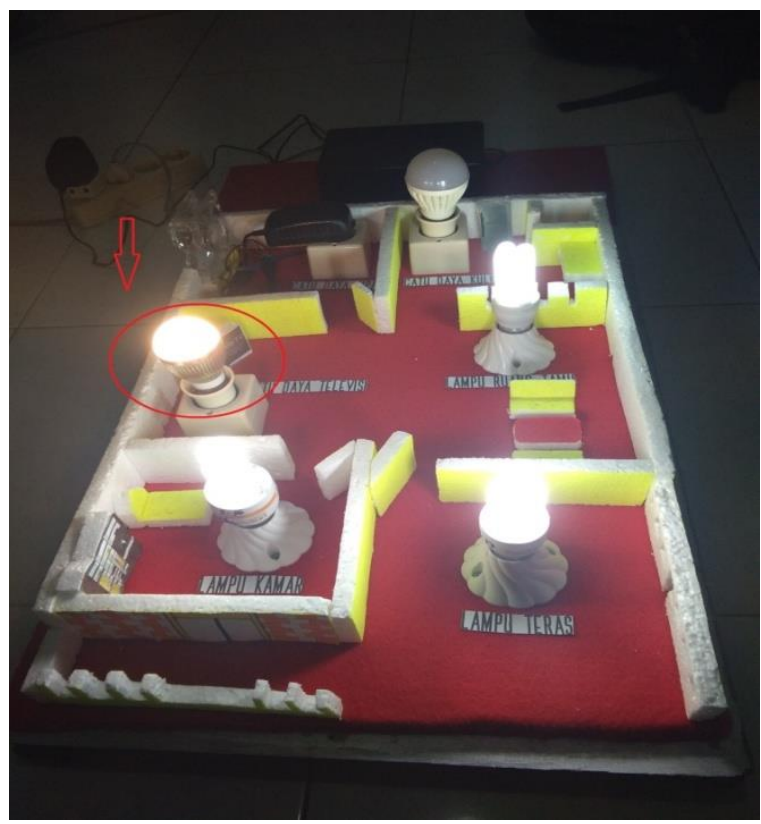

Gambar 8. TV Dalam Keadaan Hidup

Pada gambar diatas simulasi alat menunjukan perangkat elektronik rumah berupa televisi dalam keadaan hidup. Tetapi perangkat televisi digantikan menggunaka lampu neon jenis $5 \mathrm{~W}$ yang dilingkari berwarna merah. 


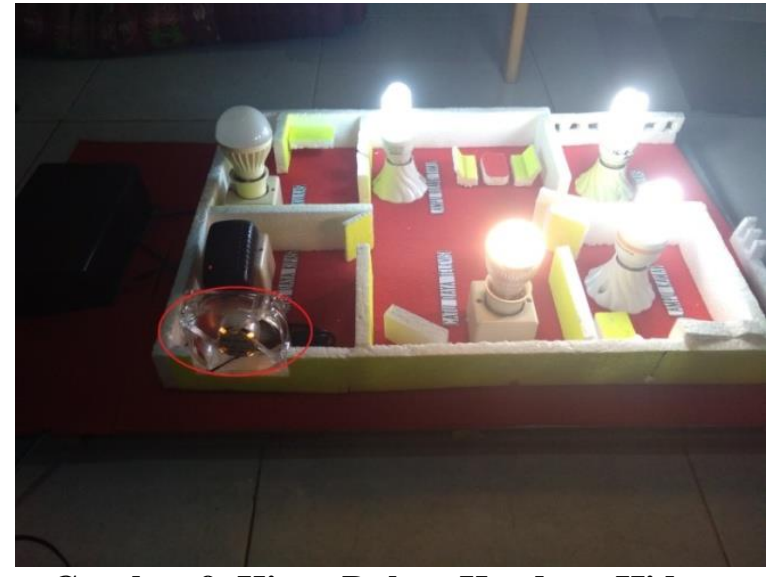

Gambar 9. Kipas Dalam Keadaan Hidup

Pada gambar diatas simulasi alat menunjukan perangkat elektronik rumah berupa kipas dalam keadaan hidup. Namun, disimulasi ini, menggunakan jenis kipas pendingin komputer (FAN).

\section{PENGUJIAN}

Tahapan pengujian sistem merupakan bentuk dari teknik menjalankan sistem pemrograman yang telah dirancang dan bertujuan untuk menguji komponen sistem yang telah dirancang apakah dapat berfungsi dengan baik.

\begin{tabular}{|l|l|c|}
\hline \multicolumn{1}{|c|}{ Data Masukan } & \multicolumn{1}{|c|}{ Hasil yang ditampikan } & $\begin{array}{c}\text { Hasil } \\
\text { Pengujian }\end{array}$ \\
\hline Tekan saklar lampu hidup & $\begin{array}{l}\text { Jika saklar dalam keadaan hidup } \\
\text { maka lampu akan hidup }\end{array}$ & Berhasil \\
\hline Tekan saklar lampu mati & $\begin{array}{l}\text { Jika saklar dalam keadaan mati maka } \\
\text { lampu akan mati }\end{array}$ & Berhasil \\
\hline Tekan saklar televisi hidup & $\begin{array}{l}\text { Jika saklar dalam keadaan hidup } \\
\text { maka televisi akan hidup }\end{array}$ & Berhasil \\
\hline Tekan saklar televisi mati & $\begin{array}{l}\text { Jika saklar dalam keadan mati maka } \\
\text { televisi akan mati }\end{array}$ & Berhasil \\
\hline $\begin{array}{l}\text { Tekan saklar kipas angin } \\
\text { hidup }\end{array}$ & $\begin{array}{l}\text { Jika saklar dalam keadaan hidup } \\
\text { maka kipas angin akan hidup }\end{array}$ & Berhasil \\
\hline $\begin{array}{l}\text { Tekan saklar kipas angin } \\
\text { mati }\end{array}$ & $\begin{array}{l}\text { Jika saklar dalam keadaan mati maka } \\
\text { kipas angin akan mati }\end{array}$ & Berhasil \\
\hline Tekan saklar kulkas hidup & $\begin{array}{l}\text { Jika saklar dalam keadaan hidup } \\
\text { maka kulkas akan hidup }\end{array}$ & Berhasil \\
\hline Tekan saklar kulkas mati & $\begin{array}{l}\text { Jika saklar dalam keadaan mati maka } \\
\text { kulkas akan mati }\end{array}$ & Berhasil \\
\hline
\end{tabular}

\section{KESIMPULAN}

Beberapa kesimpulan yang dapat diambil setelah diselesaikannya Rancang bangun dengan sistem pengendalian barang elektronik rumah dan suhu ruangan berbasis website maka dapat ditarik kesimpulan sebagai berikut :

a. Dengan aplikasi ini pengontrollan elektronik rumah seperti lampu, televisi, kipas angin, dan kulkas dapat dilakukan menggunakan website dari mana saja, asalkan terhubung dengan jaringan internet.

b. Pengujian akses Web server dan pengendalian dari berbagai perangkat berjalan dengan baik. Perangkat seperti handphone dan laptop dapat mengakses web server.

c. Hasil dari elektronik rumah seperti lampu, televisi, kipas angin, dan kulkas juga berjalan dengan baik dan sesuai dengan rancangan sebelumnya.

d. Jaringan yang dibuat ada 2, yaitu jaringan luar dan jaringan lokal. Jaringan luar merupakan jaringan untuk user mengakses web server dan jaringan lokal merupakan jaringan yang terhubung dengan hardware.

\section{SARAN}

Berdasarkan hasil yang telah diperoleh, maka beberapa saran yang dapat dilakukan untuk penelitian selanjutnya adalah sebagai berikut:

a. Pengontrollan dapat dikembangkan untuk mengontrol alat elektronik pada rumah diharapkan lebih banyak.

b. Waktu pengontrolan kurang maksimal, diharapkan ada pengembanganpengembangan dalam pengontrolan elektronik rumah dengan waktu yang lebih baik peneliti sebelum nya.

\section{DAFTAR PUSTAKA}

Setiani, A. R., dkk, 2015 , Pengendalian Lampu Rumah Berbasis Mikrokontroler Arduino Menggunakan Smartphone Android, Jurnal, Vol 8, No 3.

Rizal, Ahmad., 2014, Pengendalian Rumah Pintar Menggunakan Jaringan Internet Berbasis Raspberry Pi.

Andrianto, dan Susanto, Arif, 2015, Aplikasi Pengontrol Jarak Jauh Pada Lampu Rumah Berbasis Android, Jurnal Teknik Informatika.

Damayanti, D., dkk, 2011, Perancangan Dan Realisasi Sistem Pengatur Suhu Ac Otomatis Berbasis Mikrokontroler.

Djuandi, Feri., 2011, Implementasi Sistem Bluetooth menggunakan Android dan Arduino untuk Kendali Peralatan Elektronik, Jurnal Teknik Elektro. 
Bishop, Owen., 2014, Pengendalian Peralatan Elektronik Rumah Tangga Menggunakan Handphone Android Berbasis Microcontroller Arduino.

Fajriyah, Siti Khusnul, 2010, Implementasi Framework Code Igniter untuk Aplikasi Situs Portal Berita, SKRIPSI Jurusan Teknik Informatika STMIK AMIKOM, Yogyakarta 